\title{
RASSF5 wt Allele
}

National Cancer Institute

\section{Source}

National Cancer Institute. RASSF5 wt Allele. NCI Thesaurus. Code C104721.

Human RASSF5 wild-type allele is located in the vicinity of $1 \mathrm{q} 32.1$ and is approximately 82 $\mathrm{kb}$ in length. This allele, which encodes RAS association domain-containing protein 5 , is involved in both tumor suppression and lymphocyte adhesion. 